\title{
Ploughing and grazing alter the spatial patterning of surface soils in a shrub- encroached woodland
}

Stefani Daryanto ${ }^{1}$, David J. Eldridge ${ }^{2,5}$ and Lixin Wang ${ }^{3,4}$

1. Evolution and Ecology Research Centre, School of Biological, Earth and Environmental Science, University of NSW, Sydney, NSW, Australia, 2052

(s.daryanto@student.unsw.edu.au)

2. NSW Office of Environment and Heritage, c/- Evolution and Ecology Research Centre, School of Biological, Earth and Environmental Science, University of NSW, Sydney, NSW, 2052, Australia (d.eldridge@unsw.edu.au)

3. Department of Earth Sciences, Indiana University-Purdue University, Indianapolis (IUPUI), Indianapolis, Indiana 46202, USA (lxwang@iupui.edu)

4. Water Research Centre, School of Civil and Environmental Engineering, University of NSW, Sydney, NSW, 2052, Australia

5. Address for correspondence: Phone: 006129385 2194, Fax: 006129385 1558, email: d.eldridge@unsw.edu.au

This is the author's manuscript of the article published in final edited form as:

Daryanto, S., Eldridge, D. J., \& Wang, L. (2013). Ploughing and grazing alter the spatial patterning of surface soils in a shrub-encroached woodland. Geoderma, 200, 67-76. http://dx.doi.org/10.1016/j.geoderma.2013.02.006

\section{Introduction}

A high degree of spatial patterning in vegetation and soil resources is a common feature of water-limited systems (e.g., Borgogno et al., 2009; Wang et al., 2009a). Such patterns can be induced by abiotic factors such as topography, fire, rainfall, wind and water erosion (e.g., Li et al., 2009; Ravi et al., 2009) or by biotic influences due to vegetation (Kefi et al., 2007), 
particularly the plant canopy (Wang et al., 2009a,b). Plants are strong biotic drivers of the distribution of soil properties, and their effects vary at spatial scales ranging from that of single plants (Jackson and Caldwell, 1993) to entire communities (Gross et al., 1995; Wang et al., 2007a). Individual plants modify their surrounding soils by accumulating nutrients, sediments and essential resources such as water, seed and organic matter around their canopies. Much of these materials are derived from biotic and abiotic processes occurring in the interspaces; the unvegetated areas between plants. The combined effect of these processes is to reinforce the 'fertile island' phenomenon around individual plants (e.g., Schlesinger et al., 1996; Wang et al., 2009c). Other biotic factor such as animal activity (i.e., grazing) could also directly, or indirectly, affect the distribution of soil properties. For example, trampling by herbivores alters soil bulk density and infiltration patterns (Stavi et al., 2008). Similarly, herbivores might indirectly affect the spatial distribution of soil properties either by: 1) removing vegetation or reducing its spatial distribution, thereby altering the capacity of patches to capture resources (Rietkerk et al., 2000), or 2) changing plant community composition and thus the quality (e.g., the C:N ratio) and quantity of litter (Chapin et al., 2002).

Overgrazing has been shown to lead to fragmentation of plant patches (Bisigato and Bertiller, 1997) through the removal of biomass of some palatable shrubs such as Acacia aneura (Tiver and Andrew, 1997). Wind erosion further removes fine soil particles and nutrients associated with the presence of grasses, enhancing the movement of resources from the interspaces to the plant patches (Li et al., 2009). In the semi-arid woodlands, this redistribution of resources changes markedly when areas of open grassland are encroached by shrubs. Increases in the density of woody plants alter the scale at which soil nutrients are distributed, from a fine scale, which corresponds to the average distance between former perennial grass tussocks, to one that matches the average spacing of individual shrub hummocks (Schlesinger et al., 1996). While progressive nutrient accumulation under shrubs is associated with grassland degradation (Augustine and Frank, 2001), grazing could further influence the soil nutrient patterning by changing the distribution of litter inputs to the soil, fragmenting the cover of biological soil crusts (Neff et al., 2005) as well as generating inputs of dung (Afzal and Adams, 1992).

Globally, the area of land affected by encroachment of woody plants has increased dramatically over the past half century (Naito and Cairns, 2011). Perceived problems of 
encroachment in pastoral enterprises have resulted in an intensification of shrub control techniques, particularly mechanical methods (e.g., Herrick et al., 2006). Grazing by domestic livestock is a typical management practice following mechanical shrub removal as managers seek to recoup some of the costs of such treatments. Previous studies in the semi-arid woodlands in eastern Australia have shown that the long-term effects of ploughing tend to increase shrub cover and density (Daryanto and Eldridge, 2010), potentially increasing the connectedness of shrub canopies and therefore the connectivity of shrub-mediated resources. Although post-ploughing shrubs and their hummocks tend to be smaller than the mature plants and hummocks that they replace, they still act as nutrient-accumulating patches (Daryanto et al., 2012), suggesting that ploughing might also increase connectivity between soil nutrients. An increase in the connectedness of woody plants (trees and shrubs) would also be mirrored in increases in the continuity of shade, with positive feedback effects on stock movement, potentially altering the distribution of dung. Given that woody plants are often highly preferred areas for animal camping (e.g., Eldridge and Rath, 2002; Milton and Dean, 2001), an increased distribution of both woody patches and dung would likely increase the heterogeneity in soil N (Afzal and Adams, 1992). However, ploughing is known to reduce biological soil crust cover and recovery is slow, even two decades after ploughing (Daryanto and Eldridge, 2010). Destruction of biological crusts increases the risk of erosion because it creates areas of bare soil and destabilises soil aggregates, resulting in the reduction of nutrient accumulation and the size of fertile islands. Because of increased woody cover connectivity and reduced soil crust cover after ploughing, it could be expected, therefore, that the spatial distribution of resources at the ploughed site would be complex, depending on the interactions of multiple factors such as grazing, changes in shrub cover and biological crust cover.

While there have been numerous studies of the effects of grazing on the spatial distribution of vegetation, there are fewer studies of soil- and soil surface-related effects, particularly in response to the physical removal of woody plants by ploughing. To fill this knowledge gap, we aimed to understand how both grazing and ploughing affected the spatial distribution of soil and surface features. In this study, we explore the effects of two land management practices, shrub removal by ploughing, and grazing by domestic herbivores, on the spatial distribution of soil nutrients and the underlying mechanisms forming such spatial patterns in an arid shrubland. First we compared differences in the spatial organisation of soil nutrients between a grazed and ungrazed site, which both had an intact shrub layer (grazing effect). 
Our second comparison examined potential ploughing effects at two sites, both of which have been grazed for more than 150 years (ploughing effect). Specifically, we expected that grazing would reduce the connectivity of shrub patches, reduce the cover of biological soil crusts, but increase the range of litter, compared with the ungrazed site. This would be expected to occur due to livestock-induced trampling and the effect that grazing animals have on the dispersal of surface litter. As the cover of litter and biological crusts could affect both soil surface carbon (C) and nitrogen $(\mathrm{N})$ pools, we expected that the spatial pattern (i.e., autocorrelation range) of litter and biological crust cover would change with grazing, and be more closely aligned with the autocorrelation range of $\mathrm{C}$ and $\mathrm{N}$, respectively. The increasing density of shrubs at the ploughed sites compared with the unploughed site would increase the connectivity i.e. the autocorrelation range, of shrub and litter cover and thus the connectivity of soil C. Similarly we expected that the autocorrelation range of biological crust cover and thus $\mathrm{N}$ would decline with ploughing due to the poor recovery of crusts after ploughing.

\section{Methods}

\subsection{Study area}

The study was conducted at 'Wapweelah', an extensive grazing property about $35 \mathrm{~km}$ west of Engonia near Bourke in north-western New South Wales, Australia (29 $16^{\prime}$ S, $145^{\circ} 26^{\prime}$ E). The site falls within Gumbalie Land System (Walker, 1991), which is dominated by mulga (A. aneura) woodlands. The landscape is characterised by sandplains with low west-east trending sandy rises and dunes of Quaternary aeolian alluvium. Minor to moderate windsheeting and watersheetings are common. The sandplain unit is mostly level, with few undulations and the slopes are less than 1\%. The soils at Wapweelah are classified as massive red earths (Gn 2.12; Northcote et al., 1975) or red earths (Stace et al., 1968) with sandy loam to loam surface texture. The maximum clay contents occur in the B horizons. These soils are formed from a wide range of parent material, including siliceous, alluvial and colluvial deposits, weathered sedimentary, metamorphic, and sub-acidic to intermediate igneous rocks on plains, slopes and broad hill crests (Stace et al., 1968). Mean annual rainfall is about 312 $\mathrm{mm}$, and about 45\% more rain falls during summer than winter (Robson, 1995).

The sandplain unit of Gumbalie landsystem is characterised by dense shrubs dominated by turpentine (Eremophila sturtii), narrow-leaf hopbush (Dodonaea viscosa var. angustissima), 
green turkey bush (E. gilesii), budda (E. mitchellii) and wild orange (Capparis mitchellii). There are few scattered trees of mulga, ironwood (A. excelsa), bimble box (Eucalyptus populnea), belah (Casuarina cristata), rosewood (Alectryon oleifolius), leopardwood (Flindersia maculosa), supplejack (Ventilago viminalis), wilga (Geijera parviflora), gidgee (A. cambagei) and brigalow (A. harpophylla). The understorey layer is sparse, and at the time of observation consisted of heavily grazed wollybutt (Eragrostis eriopoda), mitchell grass (Thyridolepsis mitchelliana), mulga oats (Monochather paradoxa), speargrass (Austrostipa scabra), other grasses and forbs. This land system is typical of areas targeted for blade ploughing (Robson, 1995; Walker, 1991).

\subsection{Experimental design}

In 1990, one area of $200 \mathrm{~m}$ x $400 \mathrm{~m}$ was established and divided into four linear plots of 100 $\mathrm{m}$ wide by $200 \mathrm{~m}$ long. Two of the four plots were then enclosed in herbivore-proof fence 6 $\mathrm{m}$ tall, and the unfenced-plots were subject to grazing by sheep, goats, cattle, kangaroos, rabbits and camels. One of both the fenced and unfenced plots was then ploughed and left the remaining unploughed, resulting in four combinations of grazing and ploughing: ploughedgrazed, ploughed-ungrazed, unploughed-grazed and unploughed-ungrazed. Ploughing was conducted with a single pass of a 4.2 m wide single-tyned 'Stationmaster' blade plough pulled by a $90 \mathrm{~kW}$ crawler tractor. Only shrubs were targeted, and examination of fallen shrubs confirmed a satisfactory ploughing effect over most of the treated area (Robson, 1995). Here we report the spatial heterogeneity of soil in three of these plots. We excluded the ploughed-ungrazed plot because it is unlikely to be applied widely be land managers as a management tool.

Within each plot we established one $10 \mathrm{~m}$ x $10 \mathrm{~m}$ quadrat and sampled the surface on a coarse $2 \mathrm{~m}$ grid ( $n=36$ ) as well as a finer grid of points that were spaced at distances of $25 \mathrm{~cm}$ apart ( $n=72)$ randomly across the quadrat ( $n=108$ in total) (Figure 1$)$. At the 108 points we estimated the cover of litter and biological crust using a small circular quadrat. Litter cover was measured as the percentage of the soil surface within the quadrat covered by debris or detached plant materials. Biological crust cover was measured as the percentage of soil covered by highly-specialised organisms comprising cyanobacteria, lichens, and mosses. We also sampled the topsoil at the 108 points using a soil core of $5.7 \mathrm{~cm}$ (radius) $\times 7 \mathrm{~cm}$ (depth). The top $7 \mathrm{~cm}$ was sampled because this is where most of the biological activity occurs. It is 
also the area in which shrubs are likely to have their greatest effect on soil and therefore where we would expect the greatest effects of grazing and ploughing. Using this procedure we were able to examine the spatial arrangement of soil nutrients and surface cover at spatial scales ranging from $25 \mathrm{~cm}$ up to about $14 \mathrm{~m}$ (Figure 1). We also mapped the location and size of all woody plants at each quadrat in order to derive the spatial distribution of these patches under the different treatments. Soil heterogeneity is highly likely to be affected by the presence of individual shrub since shrubs do not form a community resembling the 'brousse tigre' vegetation of southern Africa but grow in isolated patches, sometimes forming islands. Many shrubs occupy bare area resulting from the loss of perennial grasses through overgrazing (Daly and Hodgkinson, 1996).

\subsection{Laboratory analysis}

We measured labile $\mathrm{C}$, inorganic $\mathrm{N}$ and net $\mathrm{N}$ mineralisation capacity in these soils because spatial patterns in soil nutrients are likely to develop for those nutrients that we assume are the most limiting in semi-arid systems (e.g., labile C and N; Schlesinger et al., 1996). Soil samples were air dried at constant temperature and humidity prior to analyses. Soil labile C was determined using the modified permanganate oxidizable C method (Weil et al., 2003), and inorganic $\mathrm{N}$ and net $\mathrm{N}$ mineralisation capacity determined using the Salicylate/Dichoroisocyanurate method and the Flow Injection Analysis was conducted using a Quikchem 8500 at $660 \mathrm{~nm}$ (Gianello and Bremner, 1986).

\subsection{Geostatistical calculations}

Geostatistical analysis was used to estimate the spatial pattern and scale of the examined soil variables (Rossi et al., 1993). Semivariograms were used to explain the semivariance $(\gamma)$ found in comparison among samples taken at increasing distance from one another $(h)$. The semivariance $\gamma$ at each $h$ is defined as:

$\gamma(h)=\sum_{i=1}^{N(h)}[z(i)-z(i+h)]^{2} / 2 N(h)$,

where $N(h)$ is the number of sample pairs separated by the lag distance $h, z(i)$ is a value measured at location $i$ and $z(i+h)$ is a value measured at location $i+h$. 
For randomly distributed data or a pure nugget model, little change in variance is encountered with increasing distance, i.e., the same sample variance is found at all scales of sampling and the semivariogram is essentially flat. For patterned data, the semivariogram first rises from a comparison of neighboring samples that are similar and autocorrelated and then reaches an asymptote, namely the sill $\left(C_{0}+C\right)$, suggesting the distance beyond which samples are independent. Nugget variance $\left(C_{0}\right)$ is the variance that occurs at a scale finer than field sampling, and a higher value indicates that more variance occurs over short distances. If a large-scale trend in the distribution of soil properties is found, however, there is no local pattern within the sampling scale, and therefore the semivariogram is linear (Schlesinger et al., 1996).

Parameters derived from the model were used to quantify three key aspects of patchiness in a variable distribution: (i) the magnitude of spatial dependence (i.e., the degree to which patches are differentiated from the surrounding area by their distinct, within-patch homogeneity), (ii) the mean diameter of those patches, and to a lesser extent, (iii) the arrangement of patches across the plot (Augustine and Frank, 2001). The magnitude of spatial structure was obtained using the index of $C /\left(C_{0}+C\right)$. A greater proportion of the total sample is spatially structured if the index approaches 1 . The mean diameter of patches and the arrangement of patches across the plot are determined by the distance separating sampling points at which semivariance reaches an asymptote or the autocorrelation range $\left(A_{0}\right)$.

\subsection{Data analysis}

For each plot, descriptive statistics (i.e., mean, median, standard deviation and coefficient of variation) was performed to calculate the overall variability for each observed variable (i.e., litter and crust cover, labile $\mathrm{C}$, inorganic $\mathrm{N}$ and net $\mathrm{N}$ mineralisation capacity). Correlation matrix for those variables was also calculated using the modified $t$-test (PASSAGE software; http://www.passagesoftware.net), which corrects the degrees of freedom based on the amount of auto-correlation in the data (Wang et al., 2007b). Point biserial correlation was also used to examine potential relationships between shrub cover (i.e., under and at the edge of the canopy vs the open) and other variables.

In the present study, semivariograms were modeled using $\mathrm{GS}^{+}$software version 9 (Robertson, 2008). There are several commonly used semivariogram models. In most cases however, 
semivariograms fitted well with spherical models, which has been proven useful in the interpretation of two-dimensional spatial data (e.g., Wang et al., 2007b). We used the spherical model to compare among the observed variables under different treatments. This model was chosen because of its suitable fit with the distribution of those variables based on three criteria: high $r^{2}$, minimal extrapolation of semivariance at spatial scale $<25 \mathrm{~cm}$, and fitted model shape (e.g., Wang et al., 2007b). In other cases, where no spatial dependence was detected, a pure nugget model was fitted.

We compared isotropic and corresponding anisotropic semivariograms at $0^{\circ}, 45^{\circ}, 90^{\circ}$, and $135^{\circ}$ and did not find any significant directional pattern. Therefore, isotropic variograms were used in all analyses. We also ensured that all data had a normal distribution, which is a prerequisite in hypothesis testing using geostatistic theory, by conducting the normal-score transformation prior to analysis (Rossi et al., 1993). To visualize and compare the effect of ploughing on crust distribution, we created inverse distance weighting (IDW) maps at the unploughed-grazed and ploughed-grazed plots. Inverse distance weighting was chosen over krigged maps for both sites because the crust distribution at the ploughed-grazed site was random, and semivariograms cannot therefore be used. Maps were produced with a quadrat size of $10 \times 10 \mathrm{~m}$ and the data that were transformed prior to semivariogram calculations were back-transformed prior to mapping (Wang et al., 2007b).

\section{Results}

In general, we observed higher variability in both litter and biological soil crust cover than labile C, particularly at the ploughed-grazed site, as indicated by the higher standard deviation (SD) and coefficient of variance (CV) for the first two parameters. We also found that inorganic $\mathrm{N}$ was more variable than the net $\mathrm{N}$ mineralisation capacity at all sites (Table 1). Shrub cover was positively correlated with litter cover, labile $\mathrm{C}$ and net $\mathrm{N}$ mineralisation capacity, but negatively correlated with soil crust cover at all sites (Table 2). The strongest association between shrub cover and other soil parameters was found at the ungrazed site, and it became weaker with the presence of grazing and ploughing. For example, we found significant correlation between shrub cover and inorganic $\mathrm{N}$ only at the ungrazed site (Table 2). We did not find, however, any significant correlation among the other observed parameters, except a positive correlation between net $\mathrm{N}$ mineralisation capacity and inorganic $\mathrm{N}$, at the unploughed-grazed site (Table 3). 


\subsection{Effects of grazing}

Consistent with our expectation, we found that the connectivity between shrub patches declined with grazing, which was indicated by the shorter autocorrelation range for shrub cover at the grazed (1.9 m; Figure $2 \mathrm{~b}$ ) than the ungrazed (3.9 m) site (Figure $2 \mathrm{a})$. These autocorrelations, however, did not correspond to those of litter cover at both grazed and ungrazed sites. The grazed site experienced an increase in the autocorrelation distance of litter cover (4.4 m; Figure 2d), indicating a spreading of litter, in contrast to the ungrazed site, which was characterised by accumulation of litter under the shrub canopies (autocorrelation range $=2.4 \mathrm{~m}$; Figure 2c). The autocorrelation range of shrub cover was closer to that of soil labile C (1.4 m) than that of litter cover at the grazed site (Figure 2f). The autocorrelation range of soil labile $\mathrm{C}$ at the ungrazed site (Figure 2e), however, was closer to that of litter cover than shrub cover.

Grazing also reduced the autocorrelation range of, and therefore the connectivity between, patches of biological crusts, with values of only $1.8 \mathrm{~m}$ at the grazed site compared with $2.5 \mathrm{~m}$ at the ungrazed site (Figures 3b \& 3a). However, this was not reflected in any decrease in the autocorrelation range of either inorganic $\mathrm{N}$ or net $\mathrm{N}$ mineralisation capacity at the grazed site (Figures 3d \& 3f). On the contrary, the autocorrelation range of crust cover at the ungrazed site ( $2.5 \mathrm{~m}$ ) was very close to that of both net $\mathrm{N}$ mineralisation capacity ( $2.6 \mathrm{~m}$; Figure 3c) and inorganic N (2.5 m; Figure 3e).

\subsection{Effects of ploughing under a scenario of continuous livestock grazing}

We found, in general, increases in the autocorrelation range of shrub cover, litter cover and soil labile C with ploughing (Figure 4). Ploughing resulted in a slight increase in the autocorrelation range of shrub cover from $1.9 \mathrm{~m}$ at the unploughed to $2.2 \mathrm{~m}$ at the ploughed site (Figures 4a \& 4b). This increase was mirrored by some increases in the autocorrelation range of litter cover (5.0 m; Figure 4d) and labile C (6.9 m; Figure 4f) at the ploughed site. In contrast, at the unploughed site, the autocorrelation range of labile $\mathrm{C}(1.4 \mathrm{~m})$ was closer to that of shrub cover $(1.9 \mathrm{~m})$ than that of litter cover (4.4 m; Figures 4a, 4c \& 4e).

Our observations also indicated that ploughing was associated with a decrease in the $C /\left(C+C_{0}\right)$ ratio for some observed parameters (Figures $\left.4 \mathrm{~d} \& 4 \mathrm{f}\right)$. For example, the $C /\left(C+C_{0}\right)$ 
ratios of litter cover $(0.56)$ and labile $C(0.22)$ at the ploughed site were lower than the corresponding values at the unploughed sites (litter cover $=0.77$; labile $\mathrm{C}=0.99$ ). These results indicated that ploughing weakened the spatial structure of litter cover and labile C.

Consistent with our expectation, ploughing was also associated with the destruction of spatial patterns in crust cover, indicated by the nugget model of crust cover observed at the ploughed site (Figure 5b). Our inverse distance map also indicated that islands of high biological soil crust cover were observed at the unploughed site, but not at the ploughed site (Figure 6). In contrast, we detected stronger spatial structures of both net $\mathrm{N}$ mineralisation capacity and inorganic $\mathrm{N}$ at the ploughed (Figures $5 \mathrm{~d} \& 5 \mathrm{f}$ ) than the unploughed site (Figures 5c \& 5e). Neither of these semivariograms had a form resembling that of crust nor litter cover. The autocorrelation range of both inorganic $\mathrm{N}$ and net $\mathrm{N}$ mineralisation capacity decreased with ploughing from 6.8 to $0.6 \mathrm{~m}$ for inorganic $\mathrm{N}$ and 12.4 to $1.1 \mathrm{~m}$ for net $\mathrm{N}$ mineralisation capacity.

\section{Discussion}

Soil resource heterogeneity is a common feature of water-limited systems (e.g., Borgogno et al., 2009; Wang et al., 2009a), and in our study, such heterogeneity is likely to be affected more by biotic factors (e.g., individual plant and soil crust typology) than abiotic factors. Although abiotic factors such as topography and rock fragment cover may also play a significant role in modifying the surrounding soils, we consider them less important, as the soil at our study site is highly weathered and the slope was negligible $(<1 \%)$.

\subsection{Shrub effects}

Consistent with the shrub concentration effect, we found that shrub cover was highly correlated with litter cover, soil labile $\mathrm{C}$, net $\mathrm{N}$ mineralisation capacity and inorganic $\mathrm{N}$, particularly at the ungrazed site (Table 2). In addition, the autocorrelation range of those soil properties, as well as litter cover, did not exceed that of shrub cover, but only at the ungrazed site (Figures 2a, 2c, 2e, 3c \& 3e). Increases in surface soil nutrients around the canopies of woody plants have been widely reported in the semi-arid literature (e.g., Wang et al., 2009a). Water, sediment and airborne nutrients tend to accumulate under shrub canopies through processes of litter fall, wind and water erosion. Canopy areas tend to experience lower 
surface temperatures and evapotranspiration, increased organic matter incorporation, nitrification, ammonification, and reduced erosion than the unvegetated interspaces (Schlesinger et al., 1996). Shrubs are also known to act as ion pumps, and shrub litter has been shown to be a source of soil nutrients (Facelli and Pickett, 1991). The cellular products of comminuted plant litter, particularly carbohydrates, amino acids and sugars, peptides and lipids, are a readily available source of labile C to the soil (Loginow et al., 1987). Shrub concentration effects have been observed for soil C (Wang et al., 2009a), soil N (Wang et al., 2007b) and soil mineral nutrients (Schlesinger et al., 1996; Wang et al., 2009c).

A significant positive association between inorganic $\mathrm{N}$ and shrub cover was also detected, but only at the ungrazed site. We attribute this to the presence of palatable, $\mathrm{N}$-fixing shrubs such as A. aneura mostly at the ungrazed sites (Daryanto and Eldridge, 2010). Shrub concentration effects, combined with the absence of stock movement under exclosure, would likely result in greater litter accumulation under the shrubs, moderating soil temperature, promoting decomposition, and increasing surface stability against rainfall (Geddes and Dunkerley, 1999). As the mechanism underlying the shrub effects on soil nutrients is likely mediated through plant litter cycling beneath the canopy, any nutrient concentration effects will likely diminish with increasing disturbance. Thus in our study, both grazing and ploughing weakened the association between shrub cover and litter cover, and therefore soil C and soil $\mathrm{N}$ (Table 2).

\subsection{Grazing and ploughing effects on shrubs and soil resources}

Consistent with earlier observations, we found that grazing reduced shrub patch size (sensu van de Koppel et al., 2002), which is apparent from the lower values for the shrub autocorrelation range under grazing (Figure 2b) than inside exclosure (Figure 2a). At the grazed site, we found a stronger effect of shrubs than litter in explaining the distribution of soil C (Figure 2), due most likely to dispersion by livestock and movement of litter towards the interspace by wind or water erosion ( $\mathrm{Li}$ et al., 2008). Our results show a strong relationship between shrub cover and labile C (Table 2) and an increase in the autocorrelation range of litter cover at the grazed compared with the ungrazed site (Figures 2c \& 2d). The ecosystem effect of litter scattering and redistribution would be to reduce the depth of litter cover and diminish its capacity to absorb energy of gravity drops from shrub foliage (Geddes and Dunkerley, 1999) or its ability to function as a resource-attenuating litter dam (Eddy et 
al., 1999; Lechmere-Oertel et al., 2005) and therefore restrict infiltration rates (Dunkerley, 2000). Thus while decomposition might occur more readily in the shrub interspaces due to high UV exposure (Throop and Archer, 2007), decomposed material in the interspaces would be more mobile than the material under the shrubs, reinforcing the resource concentration under shrubs.

Both grazing and ploughing had marked effects on soil crusts. Grazing reduced the connectivity between patches of biological soil crust, though the effect was less than expected, with a decrease in the separation distance from 2.5 to $1.8 \mathrm{~m}$ (Figures 3a \& 3b). Ploughing altered crusts from a separation distance of about $1.8 \mathrm{~m}$ to a complete destruction of spatial pattern, which is apparent in the inverse distance map (Figure 6). Indeed the adverse effects of mechanical disturbance by ploughing on soil crusts was still evident at our sites almost two decades after ploughing, even under exclosure (Daryanto and Eldridge, 2010). In functional, undisturbed woodland, biological soil crusts are common components of the interspaces between shrubs where they protect the soil against wind and water erosion and are important drivers of the nutrient economy of semi-arid soils. Reduced biological crust cover is, however, a typical response to increased disturbance in semi-arid environments. Crust destruction would be expected to reduce their capacity to fix $\mathrm{N}$, as evidenced by the low correlation coefficients between biological soil crust cover and $\mathrm{N}$ at grazed sites (Table 3). More subtle changes in crusts including a reduction in cover or richness by trampling, even in small patches, would be expected to reduce the activity of enzymes in the crust and therefore impair nutrient cycling (Maestre et al., 2011).

Our results imply that inputs of dung from sheep and goats, the main vertebrate grazers at our study site, play an important role in determining the distribution of soil resources, particularly N. Grazing is known to promote fine-scale $(<25 \mathrm{~cm}$ ) heterogeneity in soil N (Augustine and Frank, 2001) as a result of scattered dung and urine inputs (Afzal and Adams, 1992). The effects of dung and urine appeared to be more pronounced than expected, given the increased autocorrelation range of both inorganic $\mathrm{N}$ and net $\mathrm{N}$ mineralisation capacity under grazing (Figure 3d \& 3f). Although inputs of $\mathrm{N}$ from dung and urine might partially counteract the negative effects of grazing, their distribution would be expected to be highly localized (Bardgett and Wardle, 2003), resulting in limited response of primary productivity to such inputs at the landscape scale. We found a pronounced effect of animal dung (and presumably nitrates in urine) in determining the spatial dependence of both inorganic $\mathrm{N}$ and net $\mathrm{N}$ 
mineralisation capacity at the ploughed-grazed site (Figure $5 d \& 5 f$ ), which would seem to correspond more to potential movement by grazing animals than to the presence or size of patches of shrub or soil crust. Increasing connectivity between shrub patches suggests a suitable environment for livestock sheltering, given the tendency of animals to use woody cover for camping and resting (Eldridge and Rath, 2002; Milton and Dean, 2001).

In contrast to the unploughed site, the autocorrelation range of soil labile $\mathrm{C}$ under ploughing was more closely related to litter cover than shrub cover (Figure 4). Indeed, shrub cover was only weakly correlated with labile $\mathrm{C}$ at the ploughed site (Table 2). This trend would be expected given the marked difference in shrub age between ploughed and unploughed plots. Most shrubs at the ploughed site would have been about 17 years old at the time of our study (Daryanto et al., 2012), having germinated about two years after the initial shrub removal program. We found no evidence of differences in shrub canopy area at the ploughed compared with the unploughed plot at either the level of the entire plot $\left(F_{1,107}=0.03, P=0.89\right)$ nor at the scale of our $100 \mathrm{~m}^{2}$ quadrats (S. Daryanto, unpublished data). However, notwithstanding these results, nutrient concentration tended to be less under younger than older shrubs (Daryanto et al., 2012) due to a number of mechanisms. Firstly, small shrubs have smaller, more open canopies (Pugnaire et al., 1996; Wezel et al., 2000) that would capture fewer soil particles (Okin et al., 2006). Secondly, less sediment adhering to the foliage reduces the potential pool of sediment for transport by stem-flow (Whitford et al., 1997). In addition, smaller shrubs would not act as strong nutrient pumps and would support lower levels of biological activities than their mature counterparts. We argue therefore that the influence of decomposed litter on soil C would be greater than any shrub accumulation effects due to weaker-functioning shrubs (Daryanto et al., 2012). Greater shrub density at the ploughed site also resulted in fewer differences between shrub canopy and open sites. Indeed, Bolling and Walker (2002) reported a greater spatial autocorrelation range for undisturbed shrublands than post-disturbance recovering shrubs due to changes in soil hydrology such as the formation of erosional gullies.

The combination of fewer nutrient 'sinks' from smaller shrubs and reduced nutrient 'source' from biological crust cover might be responsible to some persistent soil and nutrient loss (Neff et al., 2005), as well as a decline to essential ecosystem processes, such as nutrient mineralisation (Barger et al., 2006). Given the key roles they play in maintaining ecosystem functions as well as prolonging recovery time, management of grazing should consider the 
maintenance of shrub and soil crust patches as they may contribute toward the reestablishment of a more highly functional ecosystem.

\section{Conclusions}

In this study, grazing and ploughing affect the spatial patterning of surface soils through biologically-mediated processes such as the removal of plant biomass and deposition of dung. Based on both conventional and geostatistical analyses of spatial patterns of soil and vegetation in a typically managed, semi-arid Australian woodland we found that soils with a long history of grazing by domestic livestock has experienced degradation, indicated by the following: (i) reduction in the autocorrelation range of shrub cover, and (ii) reduction in the shrub concentration effects by diminishing the patch size, resulting in a decrease in the spatial range of soil labile C. Similarly, ploughing caused the disappearance in the spatial pattern of soil biological crusts. Our study emphasizes the importance of vegetation and soil crust cover in maintaining the functioning of arid ecosystem in Australia. Given the indiscriminate nature of ploughing (e.g., reducing overall shrub diversity) and the lack of sustained control, we suggest that ploughing is an inappropriate form of land management in this semi-arid landscape. Management of grazing is therefore crucial in determining the existence of resource-accumulating patches (i.e., shrubs and crusts) and long-term consequences of their loss.

\section{Acknowledgement}

The exclosures were originally established by David Robson under funding from the NSW Government's Environmental Trust Fund. We are grateful to the owners and managers of 'Wapweelah' for allowing us access to their property and for maintaining the exclosures. We thank Niki Huang for assistance with field sampling, and Terry Koen and Bryce Kelly for sharing their knowledge of statistic analyses. This study was supported by a $\mathrm{PhD}$ scholarship from AusAID. Lixin Wang was supported by a Vice-Chancellor's Postdoctoral Research Fellowship from the University of New South Wales.

\section{References}


Afzal, M., and Adams, W.A., 1992. Heterogeneity of soil mineral nitrogen in pasture grazed by cattle. Soil Sci. Soc. Am. J. 56, 1160-1166.

Augustine, D.J., and Frank, D.A., 2001. Effects of migratory grazers on spatial heterogeneity of soil nitrogen properties in a grassland ecosystem. Ecology 82, 3149-3162.

Bardgett, R.D., and Wardle, D.A., 2003. Herbivore-mediated linkages between aboveground and belowground communities. Ecology 84, 2258-2268.

Barger, N.N., Herrick, J.E., van Zee, J., and Belnap, J., 2006. Impacts of biological soil crust disturbance and composition on $\mathrm{C}$ and $\mathrm{N}$ loss from water erosion. Biogeochemistry 77, 247-263.

Bisigato, A.J., and Bertiller, M.B., 1997. Grazing effects on patchy dryland vegetation in northern Patagonia. J. Arid Environ. 36, 639 -653.

Bolling, J.D., and Walker, L.R., 2002. Fertile island development around perennial shrubs across a Mojave Desert chronosequence. West. N. Am. Naturalist 62, 88-100.

Borgogno, F., D’Odorico, P., Laio, F., and Ridolfi, L., 2009. Mathematical models of vegetation pattern formation in ecohydrology. Rev. Geophys. 47(RG1005), doi:10.1029/2007RG000256.

Chapin, F.S., Matson, P.A., and Mooney, H.A., 2002. Principles of Terrestrial Ecosystem Ecology. Springer Science+Business Media, New York.

Daly, R. L., and Hodgkinson, K. C., 1996. Relationships between grass, shrub and tree cover on four landforms of semi-arid eastern Australia, and prospects for change by burning. Rangel. J. 18, 104-117.

Daryanto, S., and Eldridge, D.J., 2010. Plant and soil surface responses to a combination of shrub removal and grazing in a shrub-encroached woodland. J. Environ. Manage. 91, 2639-2648. 
Daryanto, S., Eldridge, D.J., and Koen, T.B., 2012. Soil nutrients under shrub hummocks and debris mounds two decades after ploughing. Plant Soil 351, 405-419.

Dunkerley, D.L., 2000. Assessing the influence of shrubs and their interspaces on enhancing infiltration in arid Australian shrubland. Rangel. J. 22, 58-71.

Eddy, J., Humphreys, G.S., Hart, D.M., Mitchell, P.B., and Fanning, P.C., 1999. Vegetation arcs and litter dams: similarities and differences. Catena 37, 57-73.

Eldridge, D.J., and Rath, D., 2002. Hip holes: kangaroo resting sites enhance the physical and chemical environment of woodland soils. Austral Ecol. 27, 527-536.

Facelli, J.M., and Pickett, S.T.A., 1991. Plant litter - its dynamics and effects on plant community structure. Bot. Rev. 57, 1-32.

Geddes, N., and Dunkerley, D., 1999. The influence of organic litter on the erosive effects of raindrops and of gravity drops released from desert shrubs. Catena 36, 303-313.

Gianello, C., and Bremner, J.M., 1986. A simple chemical method of assessing potentially available organic nitrogen in soil. Commun. Soil Sci. Plant 17, 195-214.

Gross, K., Pregitzer, K., and Burton, A., 1995. Spatial variation in nitrogen availability in 3 successional plant-communities. J. Ecol. 83, 357-367.

Herrick, J.E., Bestelmeyer, B.T., Archer, S.R., Tugel, A.J., and Brown, J.R., 2006. An integrated framework for science-based arid land management. J. Arid Environ. 65, 319-335.

Jackson, R., and Caldwell, M., 1993. Geostatistical patterns of soil heterogeneity around individual plants. J. Ecol. 81, 683-692.

Kefi, S., Rietkerk, M., Alados, C.L., Pueyo, Y., Papanastasis, V.P., ElAich, A., and de Ruiter, P.C., 2007. Spatial vegetation patterns and imminent desertification in Mediterranean arid ecosystems. Nature 449, 213-217. 
Lechmere-Oertel, R.G., Cowling, R.M., and Kerley, G.I.H., 2005. Landscape dysfunction and reduced spatial heterogeneity in soil resources and fertility in semi-arid succulent thicket, South Africa. Austral Ecol. 30, 615-624.

Li, J., Okin, G.S., Alvarez, L., and Epstein, H., 2008. Effects of wind erosion on the spatial heterogeneity of soil nutrients in two desert grassland communities. Biogeochemistry, 88, 73-88.

Li, J., Okin, G.S., and Epstein, H.E., 2009. Effects of enhanced wind erosion on surface soil texture and characteristics of windblown sediments. J. Geophys. Res. 114(G02003), doi:10.1029/2008JG000903.

Loginow, W., Wisniewski, W., Gonet, S.S., and Ciescinska, B., 1987. Fractionation of organic carbon based on susceptibility to oxidation. Pol. J. Soil Sci. 20, 47-52.

Maestre, F.T., Bowker, M.A., Canton, Y., Castillo-Monroy, A.P., Cortina, J., Escolar, C., Escudero, A., Lázaro, R., and Martínez, I., 2011. Ecology and functional roles of biological soil crusts in semi-arid ecosystems of Spain. J. Arid Environ. 75, 12821291.

Milton, S.J., and Dean, W.R.J., 2001. Seeds dispersed in dung of insectivores and herbivores in semi-arid southern Africa. J. Arid Environ. 47, 465-483.

Naito, A.T., and Cairns, D.M., 2011. Patterns and processes of global shrub expansion. Prog. Phys. Geog. 35, 423-442.

Neff, J.C., Reynolds, R.L., Belnap, J., and Lamothe, P., 2005. Multi-decadal impacts of grazing on soil physical and biogeochemical properties in southeast Utah. Ecol. Appl. 15, 87-95.

Northcote, K.H., Hubble, G.D., Isbell, R.F., Thompson, C.H., Bettenay, E., 1975. A Description of Australian Soils. CSIRO, Australia. 
Okin, G.S., Gillette, D.A., and Herrick, J.E., 2006. Multi-scale controls on cosequences of aeolian processes in landscape change in arid and semi-arid environments. J. Arid Environ. 65, 253-275.

Pugnaire, F.I., Haase, P., Puigdefabregas, J., Cueto, M., Clark, S.C., and Incoll, L.D., 1996. Facilitation and succession under the canopy of a leguminous shrub, Retama sphaerocarpa, in a semi-arid environment in south-east Spain. Oikos 76, 455-464.

Ravi, S., D’Odorico, P., Wang, L., White, C., Okin, G., Macko, S., and Collins, S., 2009. Post-fire resource redistribution in desert grasslands: a possible negative feedback on land degradation. Ecosystems 12, 434-444.

Rietkerk, M., Ketner, P., Burger, J., Hoorens, B., and Olff, H., 2000. Multiscale soil and vegetation patchiness along a gradient of herbivore impact in a semi-arid grazing system in West Africa. Plant Ecol. 148, 207-224.

Robertson, G.P., 2008. GS ${ }^{+}$: Geostatistics for the Environmental Sciences. Gamma Design Software, Plainwell, Michigan, USA.

Robson, A.D., 1995. The effects of grazing exclusion and blade-ploughing in semi-arid woodland vegetation in north-western New South Wales over 30 months. Rangeland J. 17, 111-127.

Rossi, R.E., Borth, P.W., and Tollefson, J.J., 1993. Stochastic simulation for characterizing ecological spatial patterns and appraising risk. Ecol. Appl. 3, 719-735.

Schlesinger, W.H., Raikes, J.A., Hartley, A.E., and Cross, A.F., 1996. On the spatial pattern of soil nutrients in desert ecosystem. Ecology 77, 364-374.

Stavi, I., Ungar, E.D., Lavee, H., and Sarah, P., 2008. Grazing-induced spatial variability of soil bulk density and content of moisture, organic carbon and calcium carbonate in a semi-arid rangeland. Catena 75, 288-296. 
Stace, H.T.C., Hubble, G.D., Brewer, R., Northcote, K.H., Sleeman, J.R., Mulcahy, M.J., Hallsworth, E.G., 1968. A Handbook of Australian Soils. Rellim Technical Publications, Glenside, South Australia.

Throop, H.L., and Archer, S.R., 2007. Interrelationships among shrub encroachment, land management and litter decomposition in a semidesert grassland. Ecol. Appl. 17, 18091823.

Tiver, F., and Andrew, M.H., 1997. Relative effects of herbivory by sheep, rabbits, goats and kangaroos on recruitment and regeneration of shrubs and trees in eastern South Australia. J. Appl. Ecol. 34, 903-914.

van de Koppel, J., Rietkerk, M., van Langevelde, F., Kumar, L., Klausmeier, C.A., Fryxell, J.M., Hearne, J.W., van Andel, J., de Ridder, N., Skidmore, A., Stroosnijder, L., and Prins, H.H.T., 2002. Spatial heterogeneity and irreversible vegetation change in semiarid grazing systems. Am. Nat. 159, 209-218.

Walker, P.J., 1991. Land Systems of Western New South Wales. Soil Conservation Service of New South Wales.

Wang, L., D'Odorico, P., Manzoni, S., Porporato, A., and Macko, S., 2009a. Carbon and nitrogen dynamics in southern African savannas: the effect of vegetation-induced patch-scale heterogeneities and large scale rainfall gradients. Climatic Change 94, 6376.

Wang, L., D'Odorico, P., Okin, G.S., and Macko, S., 2009c. Isotope composition and anion chemistry of soil profiles along the Kalahari Transect. J. Arid Environ. 73, 480-486.

Wang, L., D'Odorico, P., Ringrose, S., Coetzee, S., and Macko, S.A., 2007a. Biogeochemistry of Kalahari sands. J. Arid Environ. 71, 259-279.

Wang, L., Mou, P.P., Huang, J., and Wang, J., 2007b. Spatial heterogeneity of soil nitrogen in a subtropical forest in China. Plant Soil 295, 137-150. 
Wang, L., Okin, G.S., Caylor, K.K., and Macko, S.A., 2009b. Spatial heterogeneity and sources of soil carbon in southern African savannas. Geoderma 149, 402-408.

Weil, R.R., Islam, K.R., Stine, M.A., Gruver, J.B., and Samson-Liebig, S.E., 2003. Estimating active carbon for soil quality assessment: A simplified method for laboratory and field use. Am. J. Alternative Agr. 18, 3-17.

Wezel, A., Rajot, J.L., and Herbrig, C., 2000. Influence of shrubs on soil characteristics and their function in Sahelian agro-ecosystems in semi-arid Niger. J. Arid Environ. 44, 383-398.

Whitford, W.G., Anderson, J., and Rice, P.M., 1997. Stemflow contribution to the 'fertile island’ effect in creosotebush, Larrea tridentata. J. Arid Environ. 35, 451-457. 


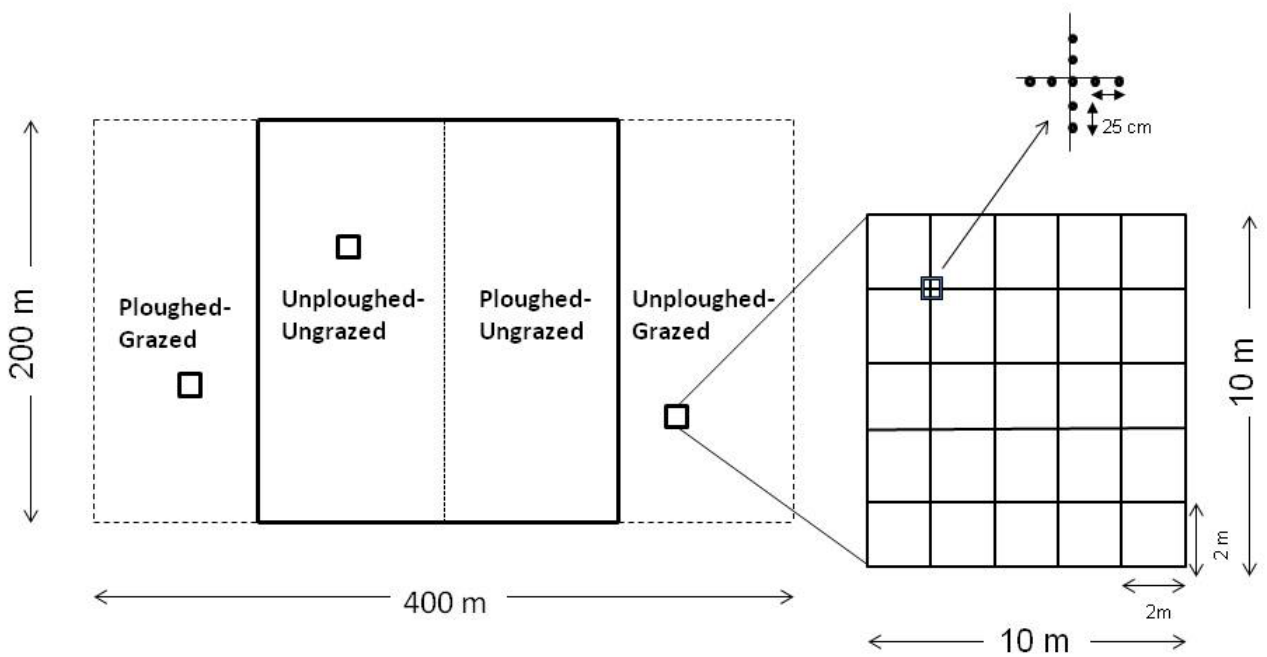

Figure 1. Sampling design for measuring surface soil condition and soil nutrient heterogeneity. A 10x10 m grid was placed in each plot and samples were taken at the 36 intersections (coarse grid, minimum sampling interval $=2 \mathrm{~m}$ ). An additional 72 points were located randomly along the grid (minimum sampling interval $=25 \mathrm{~cm}$ ) 


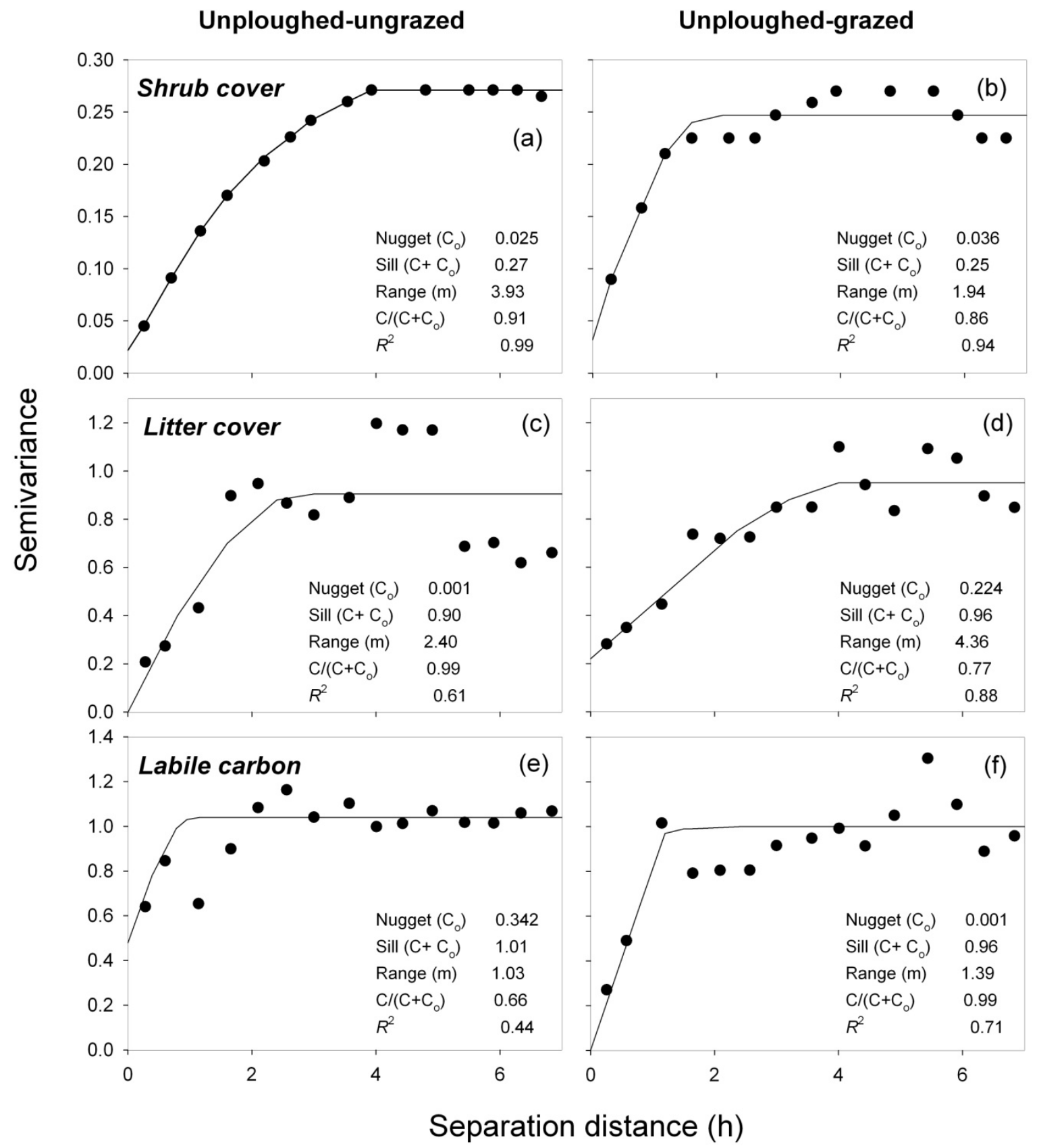

Figure 2. Semivariograms for shrub cover, litter cover and labile $C$ at the unploughedungrazed (a, c, e) and unploughed-grazed sites (b, d, f). All semivariograms used spherical models. 


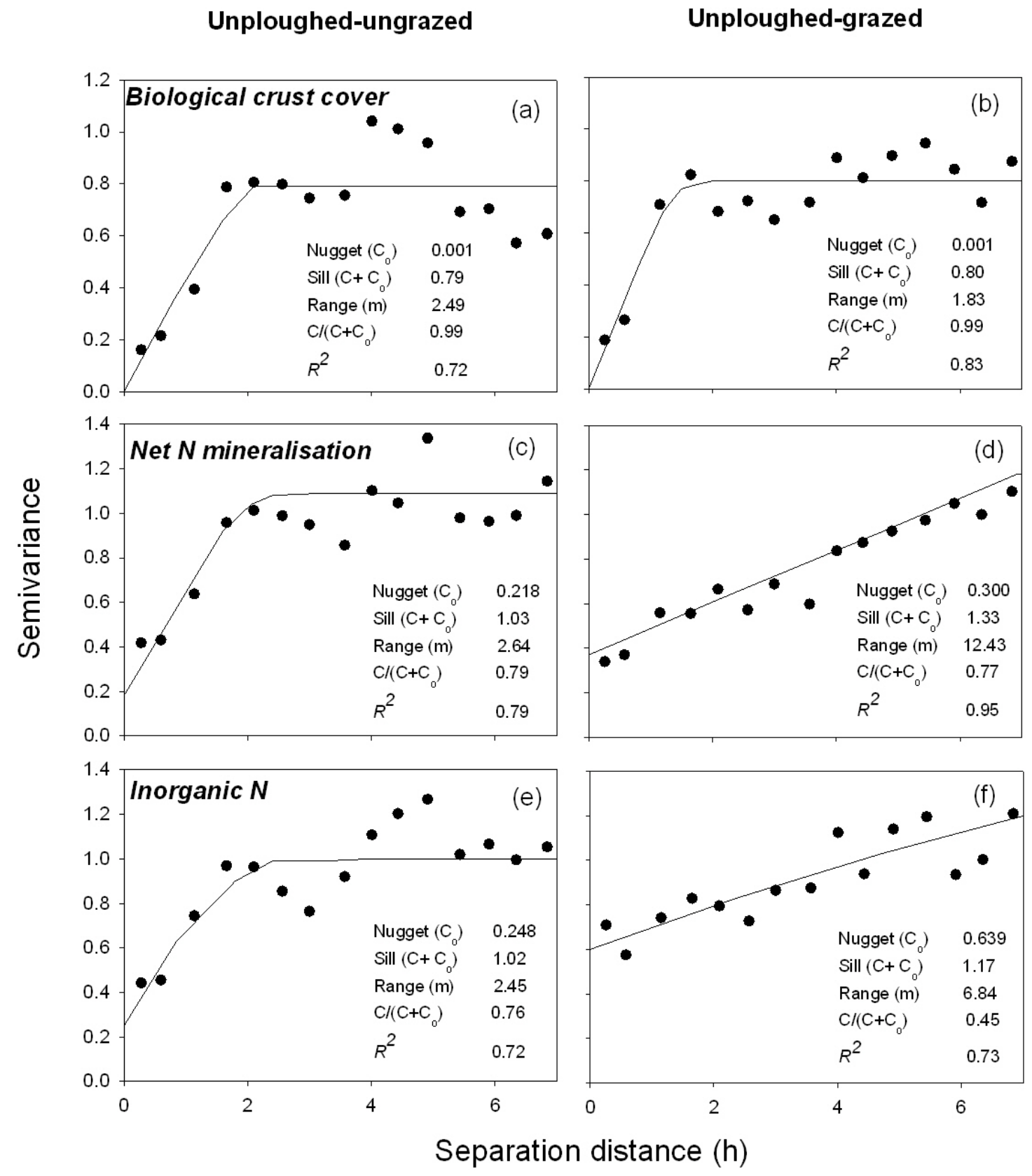

Figure 3. Semivariograms for biological crust cover, mineralisable and mineral $\mathrm{N}$ at unploughed-ungrazed (a, c, e) and unploughed-grazed sites (b, d, f). 
Unploughed-grazed

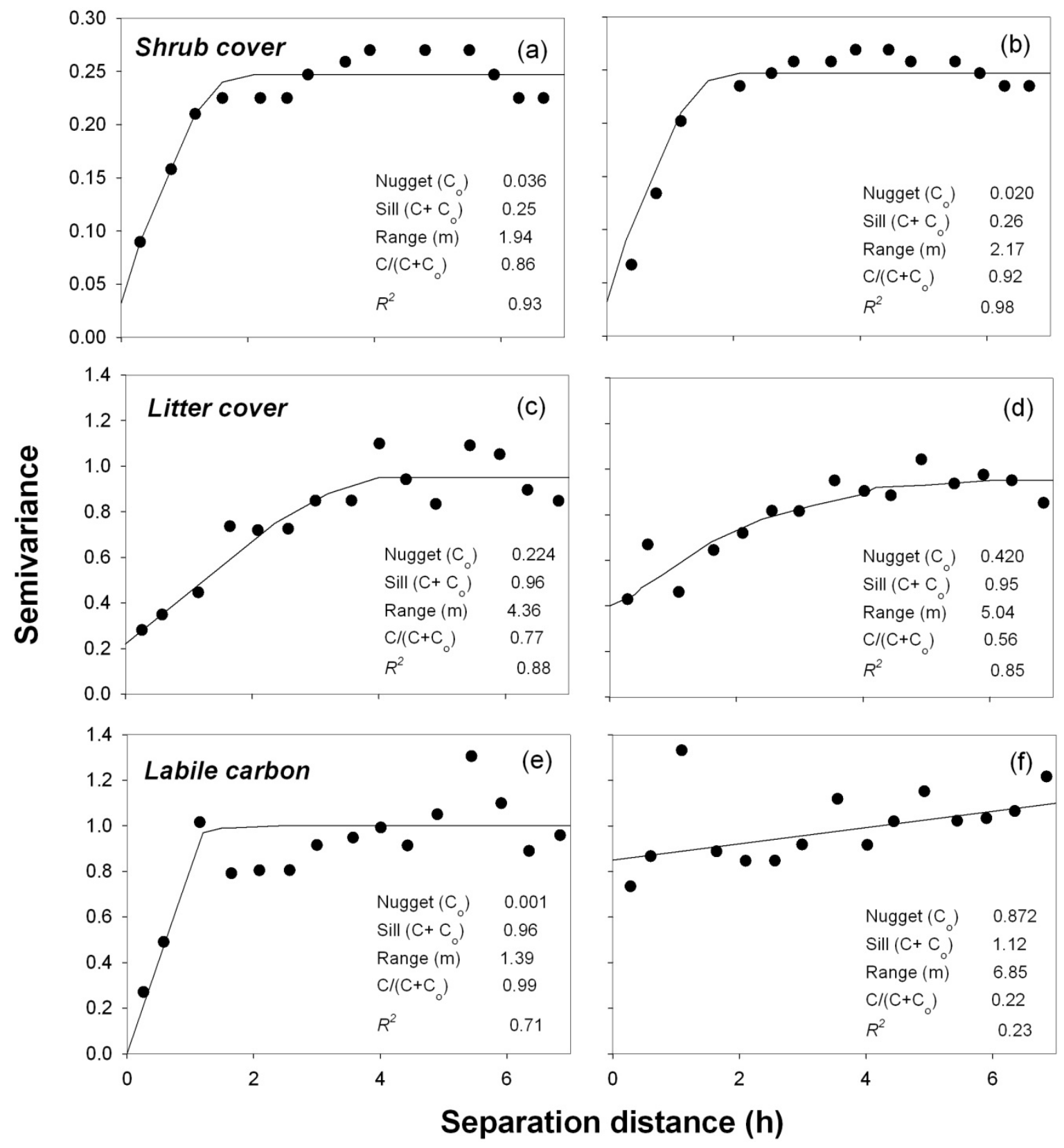

Figure 4. Semivariograms for shrub cover, litter cover and labile $\mathrm{C}$ at the unploughed-grazed (a, c, e) and the ploughed-grazed sites (b, d, f). 
Unploughed-grazed
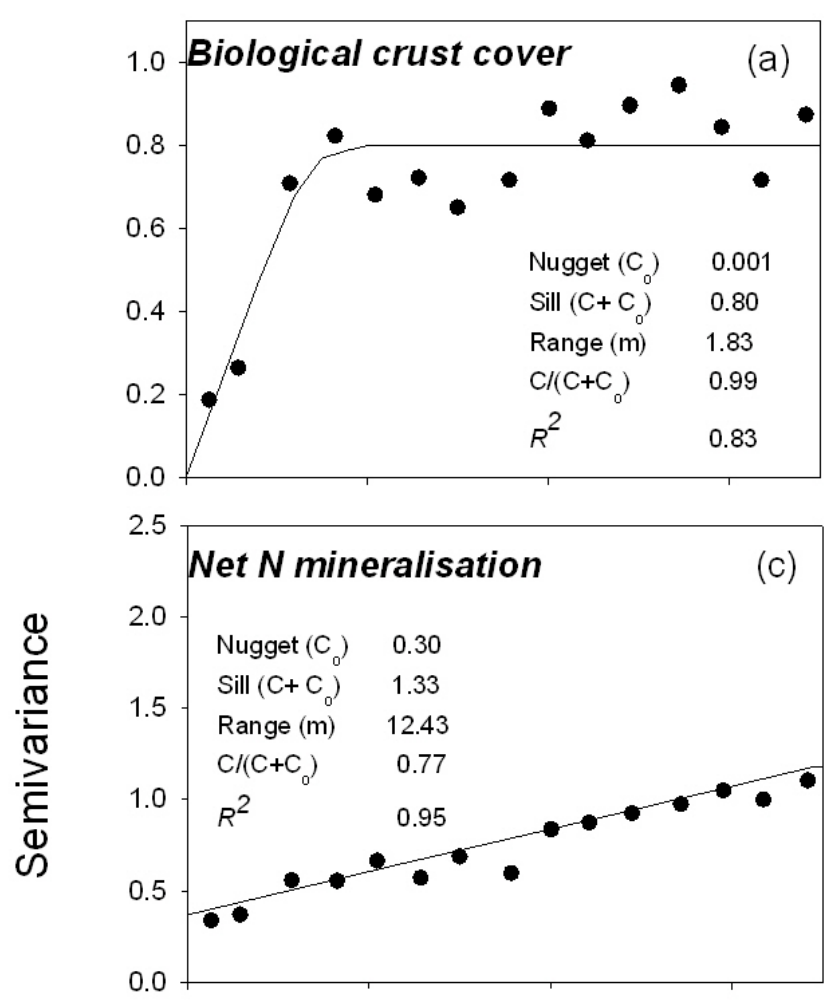

1.4

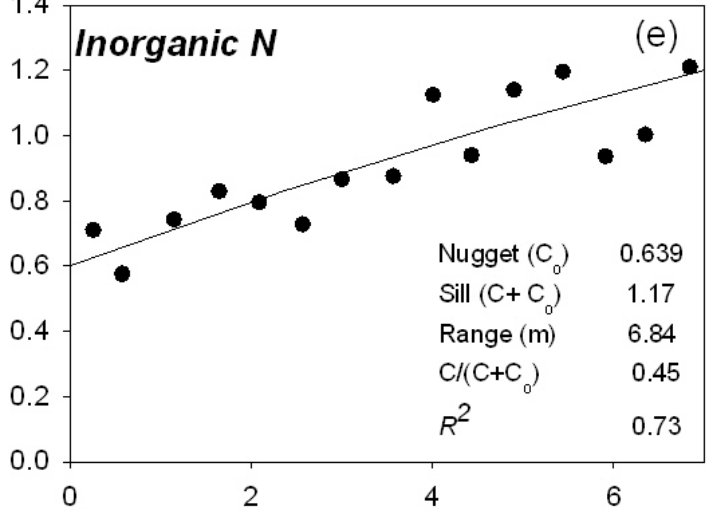

Ploughed-grazed
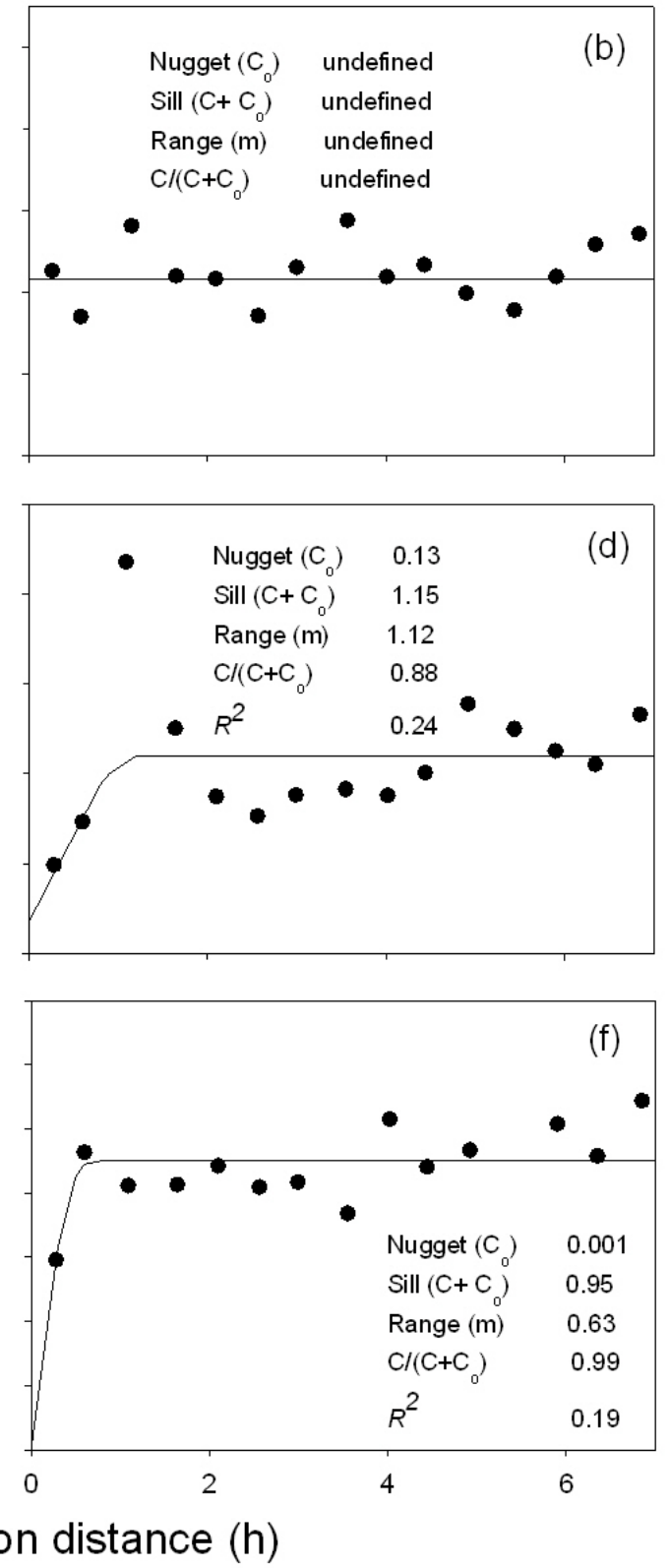

Figure 5. Semivariograms for biological crust cover, mineralisable and mineral $\mathrm{N}$ at the unploughed-grazed (a, c, e) and ploughed-grazed sites (b, d, f). 
1

Unploughed-grazed

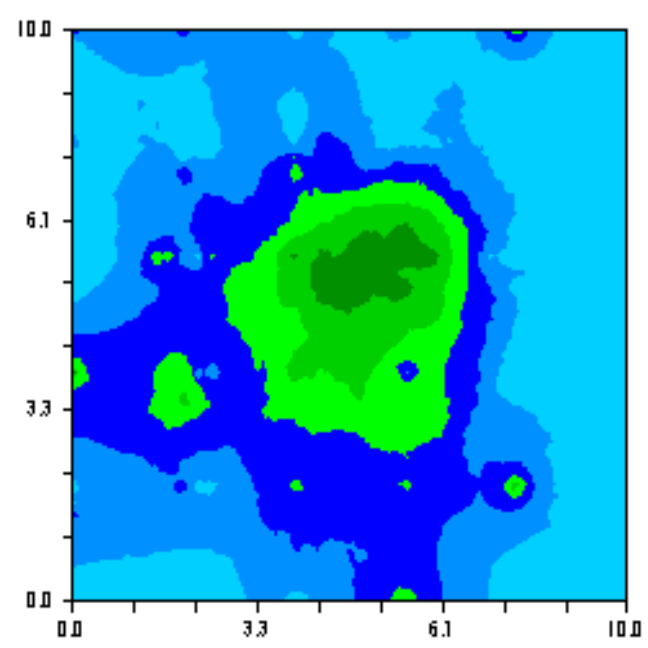

Ploughed-grazed

Cover (\%)
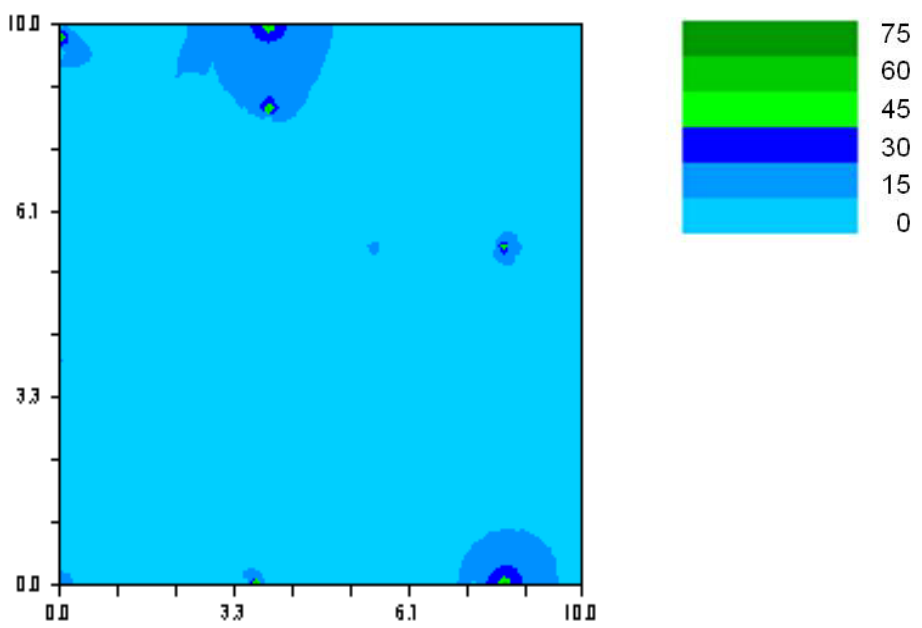

2

3 Figure 6. Interpolated map of biological crust cover using the inverse distance weighting

4 (IDW) method at unploughed-grazed and ploughed-grazed sites. Cover ranges from $<15 \%$

5 (light blue) to $>75 \%$ (dark green).

6 